\title{
From the Desk of Editor-in-Chief
}

\section{Ramesh Chandra Sinha ${ }^{1}$}

Published online: 19 June 2019

(C) ICPR 2019

Journal of Indian Council of Philosophical Research (JICPR) was published by well-meaning editors with deep philosophical insight and great social concern. While writing editorial I do remember them with reverence. I am grateful to Professor Daya Krishna who worked in late age to edit the journal meticulously. He established a great reputation to the journal amongst scholars of East and West. I am thankful to the newly constituted board of editors and members of the Council for providing us moral, academic and administrative support. I am also thankful to Springer for bringing the volume regularly.

The primary aim of the journal is to discuss on the philosophical tradition of India. It also promotes dialogue with Anglo-American and Continental philosophy. Philosophising needs no geographical boundaries. Philosophising is conceptualising. Concepts are clothed in language. Hence, linguistic analysis is an important function of a philosopher. But in the post-modern age philosophy is not restricted to linguistic analysis. In Indian context, philosophising is cultural and spiritual activity. Philosophy is concerned with vision and wisdom. Philosophy is not simply ratiocination or logical chopping of concepts. It is deeply concerned with life and experiences. Philosophising is a kind of systematic reflections. Though Indian philosophy is primarily intuitive, the role of reason is also very important. Reason paves the way for higher intuitive or spiritual vision. In recent past, an attempt has been made through JICPR to introduce the readers and scholars to the spirit and outlook of Indian philosophy. We preserve the distinctive marks of spiritual and practical outlook of Indian philosophy.

Indian philosophy refers to ancient and contemporary both. The principle schools are classified as either orthodox or heterodox-āstika and nāstika. Though Vedānta system is dominant in India, logical deliberations are quite remarkable. The Nyāya-sūtra is an ancient Sanskrit text composed by Akșapāda Gautam. It focuses on knowledge and logic. The Nyāya-sütras cover a wide range of topics including Tarka-vidy $\bar{a}$, the science of $v \bar{a} d a-v i d y \bar{a}$. Formal mathematics and the philosophy of science is based on the belief that logical truths are universal. Logic is considered as the science of the formal principle of reasoning. Indian logic dates back to the

Ramesh Chandra Sinha

rcsinha22@gmail.com

1 Indian Council of Philosophical Research, New Delhi, India 
$\bar{a} n v \bar{l} k s ̦ a k \bar{l}$ of Kauțilya. The classical tradition of Nyāya continued to develop through early modern times in the form of Navya-Nyāya school of logic. Indian logic does not stipulate watertight division between deductive and inductive inferences. So we urge today to develop our integral logic and philosophy so that we can contribute substantially to the world of philosophy and culture.

This volume comprises nine articles written by eminent scholars. S.R. Bhatt in his article, 'Revisiting Indian Mode of Philosophizing', adheres that Indian Philosophy is holistic and integral in its approach. It has to be revisited and re-interpreted in contemporary context then only its real message can be demonstrated to the world. Malcolm R. Printer in his article, 'Centrality of Sampajāno in the Buddha's Teachings', upholds that mindfulness deserves our special attention to get rid of sufferings. Jolly Thomas in his article, 'Resolving Scheffler and Chomsky's Problems on Quine's Criterion of Ontological Commitments', resolves the problem raised by Scheffler and Chomsky against Quine's criterion of ontological commitment. Sarthak Ghosh in his article, 'Introspection and Primacy of Perception: A Critical Reflection on Nä̈ve Realism', discusses fundamental issues in philosophy of perception. Sushruth Ravish in his article, 'The Predicament of Moral Epistemology', tries to show that philosophers working in moral epistemology either conceptualise it as an application of epistemology to moral beliefs or as encompassing issues of epistemic access to moral truth. The paper entitled 'Chomskyan Theory of Language: A Phenomenological Re-evaluation' by Shiva Rahman pertains to the enquiry into the phenomenon of language. In this paper, he contends that there are certain conceptual issues pertaining to very method of object and modality of Chomskyan project. The paper entitled 'Some Aspects of the Arcane Nature of Quantum Mechanical Theory and Distinctive Forms of Realism Arising Out of It', by Amitabha Gupta, is devoted to discuss the underlying logic and algebra of the classical mechanics and quantum mechanics, their syntax and semantics. Author has argued his views up to Distinctive Forms of Realism. The paper, entitled 'The Plausibility and Significance of Underdetermination Arguments' jointly by Abhishek Kashyap and Vikram S. Sirola, claims that empirical evidence fails to provide sufficient grounds for choosing a theory over its rivals. Authors have tried to evince that sticking with one's own theory in the face of underdetermination leads to a distinct type of disagreement.

I release the May-August 2019 issue of JICPR to our readers, researchers and academic community at large. The editor-in-chief welcomes your suggestions.

R.C. Sinha

Editor-in-Chief

Publisher's Note Springer Nature remains neutral with regard to jurisdictional claims in published maps and institutional affiliations. 